\title{
VRYHEID EN GEBONDENHEID IN DIE EKONOMIE VAN DIE REPUBLIEK VAN SUID-AFRIKA
}

Inleiding

Toe ek ingewillig het om u toe te spreek oor "Vryheid en gebondenheid in die Ekonomie van die Republiek van SuidAfrika" het ek nie besef dat dit 'n onderwerp is wat veel meer diepgaande studie vereis as waartoe iemand wat tot 'n groot mate die kantoor en studeerkamer verruil het vir die plaas in staat is nie. Ek is dus bevrees dat ek nie reg sal kan laat geskied aan so 'n belangrike onderwerp nie en u hoë verwagtings waarskynlik sal teleurstel.

My eerste probleem was om te bepaal wat onder ,gebondenheid" verstaan word. In 'n absolute sin sou dit alle faktore, en dus ook die fisies natuurlike faktore, insluit wat perke stel aan die uitlewing van die mens op die ekonomiese terrein. So 'n wye vertolking sou ons egter te ver voer en uit die feit dat "gebondenheid" teenoor „vryheid" gestel word, neem ek aan dat ek myself moet beperk tot bindings wat setel in die mens self as 'n skepsel van God.

Vir die doeleindes van hierdie lesing wil ek die bindings saamvat in drie hoofgroepe, naamlik:

(a) die wat gemik is op die voorkoming van die uitbuiting van ons medemens;

(b) die wat voortvloei uit ons rasseverhoudings, en

(c) die wat meer in besonder spruit uit die tradisie en lewensbeskouing van die individu en as rigsnoer dien vir sy persoonlike optrede op die ekonomiese terrein.

Om hierdie bindings te kan begryp is dit noodsaaklik om 'n oomblik stil te staan by die wese van ons ekonomiese stelsel in die Republiek.

Wese van ons ekonomiese stelsel

Die ekonomie van die Republiek dra die stempel van ons blanke beskawing wat berus op die kapitalistiese stelsel met sy kenmerke van privaat inisiatief, individuele besitreg en die winsmotief. Hierdie stelsel het ons geërf van die Westerse lande waar dit die hoogste peil van materiële welvaart tot stand gebring het wat die mensdom ooit geken 
het. Dit is hierdie stelsel wat ook die Republiek ekonomies ver laat uittroon bo enige ander land in Afrika.

Dit is egter nie die stelsel as sulks wat materiële welvaart verseker nie, maar wel die innerlike gesindheid van die draers van die stelsel. Sonder die individualisme van die Westerling is die kapitalistiese stelsel ondenkbaar. Sy individualisme maak van hom ' $n$ eensame wese wat onvermoeid die versameling van aardse besittings nastreef. Maar dit is juis hierdie strewe na die versameling van aardse besittings en die daarmee gepaardgaande winsmotief wat die gevaar van uitbuiting van sy medemens inhou. Daarom word in die Republiek, net soos in die meeste ander beskaafde lande, van owerheidsueë sekere beperkings op die ekonomiese vryheid van die individu gestel.

\section{Bindings gemik op voorkoming van uitbuiting van die individu}

In die Republiek is daar 'n hele reeks van sodanige bindings. Ons dink hier in die eerste plek aan die Arbeidswetgewing en Fabriekswetgewing wat die vryheid van die ondernemer inkort met betrekking tot die lone wat hy mag betaal en die toestande waaronder sy werknemers werk. Waar ons in die Republiek te doen het met 'n feitlik kroniese surplus van ongeskoolde arbeid is veral die loonwetgewing van belang, waaronder op aanbeveling van die Loonraad, minimumlone vasgestel word vir bedrywe waar daar geen loonooreenkomste tussen werkgewers en werknemers bestaan nie.

Dan is daar ook sekere magte by wetgewing aan die Regering opgedra om die uitbuiting van die publiek deur monopolistiese organisasies aan bande te lê. Prysbeheer is ook 'n belangrike beperking op die vryheid van die ondernemer.

Op die gebied van die Landbou is daar 'n hele reeks van maatreëls soos die bemarkingswet wat wel bedoel is om die belange van die boeregemeenskap as geheel te bevorder maar wat tog belangrike inkortings van die vryheid van die individuele boer inhou.

Verder is daar die gesondheidswetgewing wat ter beskerming van die volksgesondheid die vryheid van die ondernemer aan bande lê ten opsigte van die aard en samestelling van produkte wat hy bemark. 
Hierdie lys van bindings op die ondernemer is geensins volledig nie maar is voldoende om aan te dui tot watter mate van owerheidsweë bindings geplaas word op die vryheid van die individue.

\section{Bindings wat voortvloei uit ons rasseverhoudings}

Bo en behalwe die bindings wat ek genoem het en wat in min of meer dieselfde vorm voorkom in die meeste Westerse lande, het ons in die Republiek sekere besondere bindings wat voortvloei uit die bestaan binne ons landsgrense van verskillende rassegroepe wat grootliks van mekaar verskil, nie alleen ten opsigte van hul trap van beskawing nie, maar ook ten opsigte van hul hele lewensuitkyk.

Selfs tussen blanke rasse waar die verskille gering is, kom daar maar gedurig wrywing voor. Ek hoef $\mathrm{u}$ slegs maar te verwys na die wrywing wat daar vandag nog bestaan tussen Oostenrykers en Italianers in die Tirool, wat na die Eerste Wêreldoorlog aan Italië oorgedra is. Nog nader tuis, dink ons aan die verhoudings tussen ons Afrikaanssprekende en Engelssprekende burgers. In werklikheid staan die twee groepe wat lewensuitkyk betref baie na aan mekaar, en tog het daar in wye kringe onder hulle ' $n$ weersydse gevoel van antipatie geheers, wat samewerking selfs op die gebied van dringende nasionale vraagstukke byna onmoontlik gemaak het. Dit is maar betreklik onlangs dat ' $\mathrm{n}$ gees van groter welwillendheid onder hulle posgevat het en die weg voorberei het vir beter samewerking.

Waar daar dus nie veel wedersydse liefde bestaan tussen enige twee rasse, hoe nou ook al verwant aan mekaar, is dit begryplik dat die blanke in die Republiek gevaar sien in die groot getalle-oorwig van die nie-blankes en maatreëls probeer tref vir die versekering van sy voortbestaan. 'n Bespreking van die meriete van al die verskillende maatreëls wat saamgevat word onder die sambreel van die beleid van afsonderlike ontwikkeling van die huidige Regering is nie hier ter sake nie - ek wil slegs konstateer dat sekere van hierdie maatreëls belangrike beperkings plaas op die ekonomiese vryheid van beide die blanke en nie-blanke individu. As voorbeelde van die bindings wat die beleid meebring wil ek hier aanhaal die beheer oor die toestroming van Bantoe na die stedelike gebiede, en werkafbakening. 


\section{Toestromingsbeheer en werkafbakening}

Ons is almal baie trots op die hoë vlug wat nywerheidsontwikkeling in ons land geneem het, veral sedert die Tweede Wêreldoorlog, en ons roem tereg op die groter welvaart wat dit vir alle lae van ons bevolking meegebring het. Ons is egter geneig om oor die hoof te sien dat hierdie ontwikkeling noodwendig moes lei tot toestroming van honderde duisende Bantoe na ons blanke stedelike gebiede. Eers toe die ontstaan ivan agterbuurtes op massale skaal gedreig het om ons blanke stede te verswelg het ons bewus geword van die ellende wat die onbeteuelde toestroming vir die Bantoe self beteken het, en het ons oë ook oopgegaan vir die gevare wat die voortduring van die toestande vir die voortbestaan van die blanke inhou. Ons eerste reaksie was om op ongekende skaal behuising te voorsien aan die Bantoe wat ons blanke ekonomie na die stede gelok het, sodat ons vandag daarmee kan spog dat ons behuisingskemas vir nie-blankes nêrens in Afrika naasteby geëuenaar word nie.

Gelyktydig is die beheer oor die toestroming van Bantoe gestadig verskerp. Die verskerping van beheer beteken natuurlik dat die Bantoe nie vry is om sy arbeid aan te bied in die mark waar hy die hoogste prys kan behaal nie, en vir die ondernemer bring dit mee dat sy vryheid om arbeid te trek van waar hy wil ingekort is. Hierdie binding het natuurlik ook voordele vir die Bantoe self in soverre dat dié wat reeds werk in die stede se lone nie omlaag gedruk word deur 'n ooraanbod van nuwe werkers nie. Ook word verseker dat redelike behuisingstandaarde vir hulle gehandhaaf kan word.

Die ander bindings wat ek as voorbeeld genoem het, naamlik werkafbakening het dieselfde uitwerking op die vryheid van die ondernemer en werker as toestromingsbeheer.

Hierdie bindings lok heelwat weerstand uit in sekere kringe en veral die ekonome hou in beginsel nie van beperkings op die ekonomiese vryheid van die individu nie. Al wat ek hieroor wil sê is dat net soos die individu in sy optrede in eie familiekring nie uitsluitlik deur ekonomiese oorwegings gemotiveer word nie, net so min kan 'n gemeenskap of volk hom uitsluitlik laat lei deur ekonomiese oorwegings. Die ekonoom kan wel wys op die ekonomiese gevolge van sekere maatreëls en moontlik die perke aandui wat die ekonomie stel aan die bewegingsvryheid van die staatsman en politikus, 
maar die keuse van uiteindelike doelwitte val buite die bestek van die ekonomiese wetenskap.

Ek wil egter 'n paar opmerkings maak oor ons verantwoordelikheid teenoor die nie-blankes. Waar ons hul vryheid om binne die blanke gebiede te werk en te verdien inkort eis ons Christelike gewete van ons dat ons, as hulle voogde, hulle moet help om 'n bestaan elders te maak. Ons kan tog seker nie ons deure vir hulle sluit as daar nie vir hulle bestaansmoontlikhede elders gevind kan word nie, want dit sou lei tot die opdamming van werkloosheid in hul eie gebiede. Soos ons almal weet, bied nerkloosheid gunstige teelaarde vir die agitator en Kommunis, en met omvangryke werkloosheid be staan daar weinig hoop dat daar veel tereg sal kom van al die mooi planne ten opsigte van groter politieke selfstandigheid vir die Bantoetuislande onder verantwoordelike politieke Bantoeleiers.

Vandaar ook die lofwaardige planne van die Regering om ontwikkeling binne die Bantoetuislande asook in die sogenaamde "grensgebiede" kragdadig aan te moedig. Miljoene rand is reeds hieraan bestee en nog baie meer miljoene sal in die toekoms bestee moet word. Soos sal blyk uit wat ek later sal sê, is dit nie 'n maklike taak om 'n onontwikkelde volk te lei op die pad na groter ekonomiese selfstandigheid nie, en die geesdrif waarmee die amptenare van die departement van Bantoe-administrasie en -ontuikkeling hulle taak in die Bantoetuislande onder moeilike omstandighede volvoer dwing mens se bewondering af.

Terloops wil ek opmerk dat diegene wat soms so verontwaardig is oor die beperkings op die Bantoe, in gedagte moet hou dat soortgelyke beperkings op die blanke in die Bantoetuislande van toepassing is. Ter beskerming van die Bantoe word die blanke nie toegelaat om eiendom daar te besit nie, om handel te dryf nie en het hy selfs 'n permit nodig om die gebiede binne te gaan.

En nou kom ek tot wat ek beskou as die belangrikste bindings, naamlik die wat spruit uit die tradisie van 'n volk en die lewensbeskouing van die individu.

Gebondenheid as gevolg van tradisie en lewensbeskouing

$\mathrm{Ek}$ het reeds vroeër gesê dat dit nie die ekonomiese stelsel as sulks is wat welvaart verseker nie maar die lewensopvatting en kwaliteit van die draer van die stelsel. 
Dit word algemeen aanvaar dat die mens of die bevolking die vernaamste bate van ' $n$ land is. Sonder die mens vind daar geen ekonomiese ontwikkeling plaas nie.

Sedert God se oordeelsuitspraak oor Adam dat hy in die sweet van sy aanskyn sy brood sal eet, is die mens se fisiese aktiwiteite hoofsaaklik gerig op die bevrediging van sy stoflike behoeftes. Dit is duidelik dat die mens se innerlike gesindheid teenoor aardse goed 'n invloed sal uitoefen nie slegs op die intensiteit waarmee hy die versameling van besittings nastreef nie maar ook op die metode waarop hy dit doen en die doel waarop die besittings aangewend of bestee word.

Aangesien die innerlike gesteldheid teenoor stoflike welvaart van mens tot mens en veral van ras tot ras verskil is dit nodig dat ons die benadering van die twee vernaamste rassegroepe (naamlik die blanke en die Bantoe) tot besittings en rykdom, afsonderlik beskou.

\section{Benadering van die blanke}

Die twee vernaamste faktore wat inwerk op die innerlike gesteldheid van die mens is ongetwyfeld sy godsdiens en kultuur. Hierdie tuee faktore is so nou verbonde aan mekaar dat ek nie sal probeer om te bepaal waar die een ophou en die ander begin nie. Inderdaad sou mens kon beweer dat, hoewel die Westerling tot 'n groot mate sy godsdiens versaak het, sy kultuur in breë trekke nog grootliks berus op die fondamente van die Christelike geloof. Dit is ook die erfenis van hierdie Christelike kultuur wat nog taamlik algemeen die ekonomiese aktiwiteite van die blanke in die Republiek van Suid-Afrika beïnvloed, hoewel sommige inwoners nie Christene is nie en andere net in naam nog Christene is.

Hoewel die Bybel geen ekonomiese handboek is nie, bevat dit nogtans 'n hele reeks van reëls wat rigting gee aan die houding van die mens teenoor aardse besittings. So is dit byvoorbeeld duidelik dat luiheid veroordeel word en dat van die mens verwag word om te woeker met sy talente. Maar dit is ewe duidelik dat aardse besittings slegs deur God aan die mens geleen is en dat hy eenmaal sal moet rekenskap gee van hoe hy hierdie besittings gebruik het. Die uitspraak dat die arbeider sy loon waardig is, bepaal wat die benadering van die werkgewer teenoor sy werknemer behoort te wees. Verder bevat die Bybel ook voorskrifte oor ander aangeleent 
hede soos woekerwins, eerlikheid en optrede teenoor die kerk en medemens op ekonomiese gebied.

In soverre hierdie voorskrifte verpligtings op ons lê ten opsigte van die gebruik van ons besittings en ons houding teenoor ons medemens, skiet ons blankes in baie opsigte ongetwyfeld ver te kort. Daar kan egter geen twyfel bestaan dat die blanke in die algemeen woeker met sy talente nie en dat sy ondernemingsgees, sy drang na 'n hoër lewenstandaard, sy arbeidsaamheid en sy spaarsin van basiese belang is in die hoë peil van ekonomiese ontwikkeling wat ons land bereik het.

\section{Benadering van die Bantoe}

Die benadering van die Bantoe ten opsigte van stoflike welvaart daarenteen, is geheel en al anders. Hy leef nog hoofsaaklik in groepsverband, en die individualisme wat as spoorslag dien vir die rustelose strewe na vooruitgang by die blanke is by hom grootliks afwesig. Die spaarsin wat so belangrik is vir die akkumulering van kapitaal wat nodig is vir ekonomiese ontwikkeling, speel by hom nog 'n geringe rol en hy heg veel meer waarde aan die vryheid om nie te werk nie as om te werk met die doel om sy besittings te vermeerder. 'n Oordrewe maar tog fundamenteel ware beeld van die houding van die meerderheid van die Bantoe ten opsigte van werk en spaarsin word goed gekenskets in die bekende verhaal van ' $n$ beampte wat werkers vir die goudmyne moes rekruteer in een van die Bantoetuislande. Hy het 'n Bantoe genader wat rustig in die son sit teen die muur van sy hut terwyl sy vrouens besig was om in sy land te werk. Hy vra toe die Bantoe om in die myn te kom werk en verduidelik dat hy goed geld kan verdien wat hom in staat sal stel om mooi klere te koop, geld aan sy familie te stuur en ook om te spaar. Hy wou toe weet waarom hy moes spaar en die antwoord was dat wanneer hy genoeg gespaar het hy uiteindelik nie meer sal hoef te werk nie. Sy reaksie was dat hy nou nie werk nie en geen sin daarin kan sien om nou te gaan werk sodat hy later nie hoef te werk nie.

So 'n houding mag vir ons blankes onbegryplik wees, maar daar steek 'n mate van wysheid hierin wat gerus ter harte geneem kan word deur baie blankes wat in hul rustelose 
ywer om aardse goedere te verwerf hulle so afsloof dat hulle op 'n vroeë ouderdom ryk weduwees agterlaat.

Dit word my vertel dat die houding wat ek geskets het vinnig besig is om te verander by baie van die Bantoe wat jare lang reeds ingeskakel is by ons blanke ekonomie, maar in die bestaansekonomie van die Bantoetuislande speel dit nog 'n belangrike rol. Dit is ook een van die groot struikelblokke wat oorkom sal moet word om volgehoue ontwikkeling in die Bantoetuislande te verseker. Tog moet ons in ons pogings om die Bantoe te lei en te help om sy tuisland te ontwikkel daarteen waak om hom nie te inspireer met so 'n gees van materialisme dat dit sal lei tot die vernietiging van baie wat mooi en waardevol in sy eie kultuur is nie.

In sekere kringe word dit reeds die Christene en veral die Calviniste teen die hoof geslinger dat hulle die weg voorberei het vir die uiterste vorm van materialisme wat so 'n belangrike rol speel in die Westerse wêreld. Myns insiens steek daar 'n mate van waarheid in die bewering dat die leer van Calvyn daartoe bygedra het om die groei van die kapitalistiese stelsel te vergemaklik deurdat dit arbeidsaamheid aangemoedig het en die deug van spaarsaamheid verkondig het. Sodoende kan deur groter produktiwiteit en besparings die middele voorsien word vir die finansiering van die grootskeepse ontwikkeling wat onder die kapitalistiese stelsel plaasgevind het. Terselfdertyd erken die Calvinisme ook 'n billike vergoeding vir die kapitaal wat aangewend word en heg ook sy goedkeuring aan die winsmotief binne sekere perke.

Dit beteken egter geensins dat die Calvinisme verantwoordelik gehou kan word vir die sondes van die kapitalisme nie. Inteendeel die Calvinis se godsdiens leer hom dat die mens persoonlik rekenskap van al sy dade sal moet gee en sy geloof in die leer van die naasteliefde belet hom om sy medemens uit te buit. Ons sou dus met veel meer reg kon beweer dat dit juis die verval van die godsdiens in die Weste is wat gelei het tot die vermaterialisering van die opdrag om te werk. Die Goddelike opdrag dat die mens in die sweet van sy aangesig sal brood eet word nou uitgeleef ter wille van die brood self, d.w.s. ter wille van die akkumulasie van rykdom en nie ter wille van die Gewer van die brood nie.

Die negering van die bindings wat die Christelike geloof aan die mens oplê het op sy beurt gelei tot toenemende inmenging deur die owerheid in die ekonomiese vryheid van 
die individu met die doel om die swakkere lede van die gemeenskap te beskerm teen uitbuiting. Tensy die Westerse wêreld sy godsdiens herontdek en hom in sy ekonomiese aktiwiteite meer laat lei deur die bindings van die geloof, loop hy gevaar dat owerheidsinmenging steeds sal toeneem totdat hy eindelik beland in ' $n$ volslae beheerde sosialistiese of kommunistiese stelsel waar daar weinig van die ekonomiese vryheid sal oorbly en waar die kapitalistiese materialisme slegs vervang sal word deur ' $n$ ander en erger vorm van materialisme.

Veral vir ons blankes hier in die Republiek is dit van groot belang dat die vryheid van die kapitalistiese stelsel getemper word deur die bindings van die Christelike geloof, want dit sal veel daartoe bydra om die gees van offervaardigheid tot stand te bring wat so noodsaaklik is as ons uerklik die nie-blankes wil help en lei om ekonomies en geestelik voortuit te gaan.

Ekonomiese adviseur

J. H. Steyn.

van die Eerste Minister.

Pretoria. 